\title{
PEMBERDAYAAN MASYARAKAT DESA SAMBIREJO YANG MENGALAMI MASALAH PENCEMARAN SUNGAI MELALUI PEMBUATAN B-FILMA (BIO FILTER LIMBAH AIR RUMAH TANGGA)
}

\author{
Bagus Setyo Pratondo $^{1 *}$, Agus Wahyu Prasetyo ${ }^{1}$, Yuliana Ristanti ${ }^{1}$, Pujiati $^{1}$ \\ ${ }^{1}$ Jurusan Pendidikan Biologi Universitas PGRI Madiun, Madiun \\ Jl. Setia Budi No. 85 Madiun 63118 \\ Penulis Korespodensi : bagussetyodcc@gmail.com
}

\begin{abstract}
Abstrak
Masyarakat sambirejo umumnya tidak produktif dalam hal mengolah dan memanfaatkan air limbah, mereka membuang air limbah tersebut langsung ke selokan yang ada di depan rumah, tanpa diolah terlebih dahulu. Akibatnya, sungai yang menjadi tempat bermuaranya selokan tercemar, warnanya menjadi coklat dan mengeluarkan bau busuk, selain bisa menyebabkan ikan-ikan mati, zat-zat polutan yang terkandung di dalam limbah juga bisa menjadi sumber penyakit, seperti kolera, disentri,dan berbagai penyakit lainya. Oleh karena itu, pemahaman masyarakat akan dampak yang ditimbulkan dari air ini perlu ditingkatkan serta pelatihan ilmu pengolahan limbah air ini perlu diterapakan dalam kehidupan sehari-hari dengan Biofilter ini agar limbah air yang ada di desa Sambirejo dapat berkurang dan untuk juga untuk mengurangi pencemaran lingkungan, serta dapat meningkatkan sumber daya manusia di Sambirejo Madiun. Hasil kegiatan sosialisasi pemberdayaan yang dicapai dan analisis kuisioner yang dibagikan sebelum sosialisasi dalah 50\% masyarakat mengetahui dampak dari limbah air rumah tangga khususnya deterjen dan $20 \%$ masyarakat mengetahui alat B-FILMA, dan analisis hasil kuisioner yang dibagikan setelah sosialisasi adalah 75\% masyarakat menjadi faham mengenai dampak dari limbah air rumah tangga khusunya deterjen dan 50\% masyarakat mengetahui alat B-FILMA.
\end{abstract}

Kata kunci: B-FILMA, pemberdayaan masyarakat, limbah air rumah tangga, limbah deterjen

\section{Pendahuluan}

Pemakaian detergen di kalangan masyarakat semaki meningkat, karena dianggap mampu membersihkan kotoran lebih efektif daripada sabun, ataupun pembersih lainnya. Selain itu detergen juga tidak terpengaruh pada kesadahan air. Dalam deterjen terkandung komponen utamanya, yaitu surfaktan, dan komponen lain seperti khlorin, fosfat, silikat, pewangi, pewarna,dll. Masyarakat beranggapan bahwa semakin banyak busa semakin baik daya kerja detergen. Padahal, kenyataannya adalah sebaliknya. Semakin banyak busa, semakin berbahaya yang dapat menimbulkan berbagai permasalahan baru, sehingga perlu adanya pemecahan atas permasalahan tersebut (Andriyani, 2010).

Madiun adalah kota yang cukup padat penduduknya. Beragam aktivitas masyarakatnya senantiasa berhubungan dengan air. Sebut saja seperti mencuci, mandi, minum, dan sebagainya. Semua membutuhkan air. Namun apabila air sisa aktivitas tersebut tidak digunakan maka kebanyakan orang akan membuangnya begitu saja. Limbah air inilah yang dapat menimbulkan pencemaran air, selain sisa detergen,rumah tangga juga menghasilkan limbah bekas air mandi.

Desa sambirejo merupakan salah satu daerah yang berada dipinggir kota madiun tepatnya sebelah barat daya dari pusat kota madiun. Sambirejo adalah desa di kecamatan Jiwan, Madiun, Jawa Timur, Indonesia. Sambirejo merupakan desa di daerah Kabupaten Madiun yang berbatasan langsung dengan Kabupaten Magetan. Desa ini terletak sekitar $4 \mathrm{~km}$ dari pusat Kota Madiun, dan sekitar 18 kilo dari pusat Kota Magetan. Kebanyakan warga Desa Sambirejo hanya mengenyam pendidikan sampai SMA saja, ini dikarenakan kurang sebagian warga merasa cukup hanya dengan pendidikan SMA, serta ketidak sanggupan mereka untuk memenuhi biaya kuliah.

Masyarakat sambirejo umumnya tidak produktif dalam hal mengolah dan memanfaatkan 
air limbah, mereka membuang air limbah tersebut langsung ke selokan yang ada di depan rumah, tanpa diolah terlebih dahulu. Akibatnya, sungai yang menjadi tempat bermuaranya selokan tercemar, warnanya menjadi coklat dan mengeluarkan bau busuk, selain bisa menyebabkan ikan-ikan mati, zat-zat polutan yang terkandung di dalam limbah juga bisa menjadi sumber penyakit, seperti kolera, disentri,dan berbagai penyakit lainya.

Masyarakat yang masih kurang peduli terhadap lingkungan. Letak desa yang terbilang dekat dengan perkotaan membuat Desa Sambirejo memiliki masalah yang sama dengan masalah di perkotaan yaitu tentang masalah pencemaran air sabun di sistem pembuangan air tepatnya di Rt/Rw 01/01 desa Sambirejo, masing-masing dari rumah warga setiap harinya selalu membuang limbah cair ke dalam sistem pembuangan tanpa melalui penyaringan, ditambah lagi adanya tempat penyembelihan babi yang pembuangan limbah cairnya dibuang langsung ke selokan utama yg menuju sungai bengawan solo, hal tersebut dapat menimbulkan pencemaran air yang dapat merusak lingkungan di sekitar Desa Sambirejo dan kawasan aliran sungai bengawan solo. Ternyata untuk menyaring limbah cairan sabun tersebut tidak begitu sulit karena dengan alat yang sederhana warga sudah bisa membuat alat penyaring limbah cairan sabun, apabila warga Desa Sambirejo dapat memanfaatkan limbah cairan sabun tersebut secara maksimal, setelah limbah cairan sabun tersebut mendapat perlakuan khusus, tentunya limbah sabun tersebut dapat bermanfaat dan pastinya banyak keuntungan yang didapat seperti mengurangi jumlah limbah cairan sabun, mengurangi tingkat pencemaran di system pembuangan air, dan dapat menggunakan kembali cairan sabun yang telah mendapat perlakuan kusus tersebut sehingga dapat menghemat pengeluaran, serta air yg telah disaring tersebut dapat digunakan kembali untuk menyiram tanaman.

Air limbah detergen termasuk polutan atau zat yang mencemari lingkungan, karena di dalamnya terdapat zat yang mencemari lingkungan karena di dalamnya terdapat zat yang disebut ABS (Alkyl Benzene Sulphonate) yang merupakan detergen tergolong keras. Detergen tersebut sukar dirusak oleh mikroorganisme (nonbiodegradable) sehingga dapat menimbulkan pencemaran lingkungan (Nusa,2009).
Seiring dengan berjalannya waktu dan pertambahan penduduk maka air limbah juga akan bertambah,yang akan berakibat pada pencemaran air maupun lingkungan, maka dari pada itu kita perlu memberi wawasan pada masyarakat akan bahaya yang dapat ditimbulkan oleh limbah cair rumah tangga.

.Berdasarkan gambaran umum masyarakat sambirejo yang masih kurang peduli terhadap lingkungan dan membuang air limbah rumah tangga khususnya limbah deterjen tersebut langsung ke selokan yang ada di depan rumah, serta masyarakat tidak produktif dalam hal mengolah limbah tersebut dan belum mengetahu cara pengolahannya serta penerapan menggunakan alat B-filma. Pemecahan masalahnya, maka diperlukan adanya solusi dalam mengatasi suatu permasalahan tersebut adalah melakukan sosialisasi Pemberdayaan Masyarakat desa Sambirejo yang mengalami masalah pencemaran sungai melalui pembuatan B-Filma (Bio Filter Limbah Air Rumah Tangga).

Pemberdayaan dimaksudkan untuk meningkatkan kesadaran masyarakat akan pentingnya mengolah limbah air rumah tangga khususnya limbah deterjen yang dapat dimanfaatkan kembali secara maksimal, memberikan pemahaman kepada masyarakat bahwa pentingnya menjaga kebersihan lingkungan, Ikut mengurangi pencemaran lingkungan di Madiun khusunya Desa Sambirejo, Serta meningkatkan sumber daya manusia serta ikut peduli terhadap lingkungan sekitar.

Artikel-artikel yang dimuat di JSS adalah artikel yang telah melalui proses penelaahan oleh Mitra Bebestari (peer-reviewers). Keputusan diterima atau tidaknya suatu artikel ilmiah di jurnal ini menjadi hak dari Dewan Penyunting berdasarkan atas rekomendasi dari Mitra Bebestari (Bhaktavatsalam \& Choudhury, 1995).

\section{Metode}

Metode pelaksanaan yang digunakan dalam sosialisai pemberdayaan masyarakat desa Sambirejo yang Mengalami Masalah Pencemaran Sungai Melalui Pembuatan B-Filma (Bio Filter Limbah Air Rumah Tangga). adalah melakukan observasi, pelaksanaan sosialisasi, pelatihan pendampingan dan evaluasi kepada masyarakat pembuatan dan penggunaan alat B-FILMA. Adapun tahap-tahap dalam pelaksanaan sosialisasi pemberdayaan masyarakat di Desa Sambirejo 
Kabupaten Madiunn adalah: 1) Obsevasi: observasi dilakukan pada awal pelaksanaan program dengan pengamatan di desa sambirejo yang mengalami masalah pencemaran limbah air rumah tangga, khususnya limbah deterjen2) Sosialisasi: dilakukan kepada masyarakat petani pentingnya pengolahan limbah air rumah tangga khususnya limbah deterjen dengan menerapkan penggunaan alat BFILMA, 3) Pelatihan: dilakukan kepada masyarakat Sambirejo dalam pembuatan alat BFILMA secara bertahap, 4) Pendampingan: dilakukan kepada masyarakat petani dalam menggunakan alat B-FILMA secara bertahap dan terus menerus.

\section{Hasil dan Pembahasan}

Kegiatan sosialisasi pemberdayaan masyarakat desa Sambirejo yang mengalami masalah pencemaran sungai melalui pembuatan BFilma (Bio Filter Limbah Air Rumah Tangga), merupakan kegiatan pemberdayaan masyarakat yang baru pertama kali dilakukan.. Program pemberdayaan masyarakat dengan sosialisai tentang bahaya pencemaran air limbah rumah tangga serta cara meningkatkan kesadarn masyarakat dalam mengolah limbah air rumah tangga khususnya limbah deterjen dengan menggunakan alat B-FILMA mengenai arti pentingnya limbah air rumah tangga khususnya limbah deterjen sebelum dibuang ke seloakan depan rumah dan yang akan menguara ke sungai. Kegiatan sosialisai pemberdayaan masyarakat dilakukan secara periodik dan terus menerus. Berdasarkan hasil kuisioner pengetahuan masyarakat desa sambirejo akan pencemaran limbah air rumah tangga, seperti pada Tabel 1 dan tabel 2.

Berdasarkan hasil angket yang diberikan kepada masyarakat Desa Sambirejo yang dibagikan sebelum pelaksanaan sosialisasi dimulai, masyarakat belum begitu mengerti mengenai dampak dari pencemaran limbah air rumah tangga (khususnya limbah deterjen yang merupakan hasil aktifitas sehari-hari dan berdasarkan hasil kuisioner masyarakat desa sambirejo masih awam dengan adanya pembuatan alat B-FILMA sebagai solusi pengolahan limbah air rumah tangga dan sebagai cara untuk mengolah limbah air rumah tangga (khususnya limbah deterjen) sebelum dibuang ke selokan yang nantinya akan menguara ke sungai.

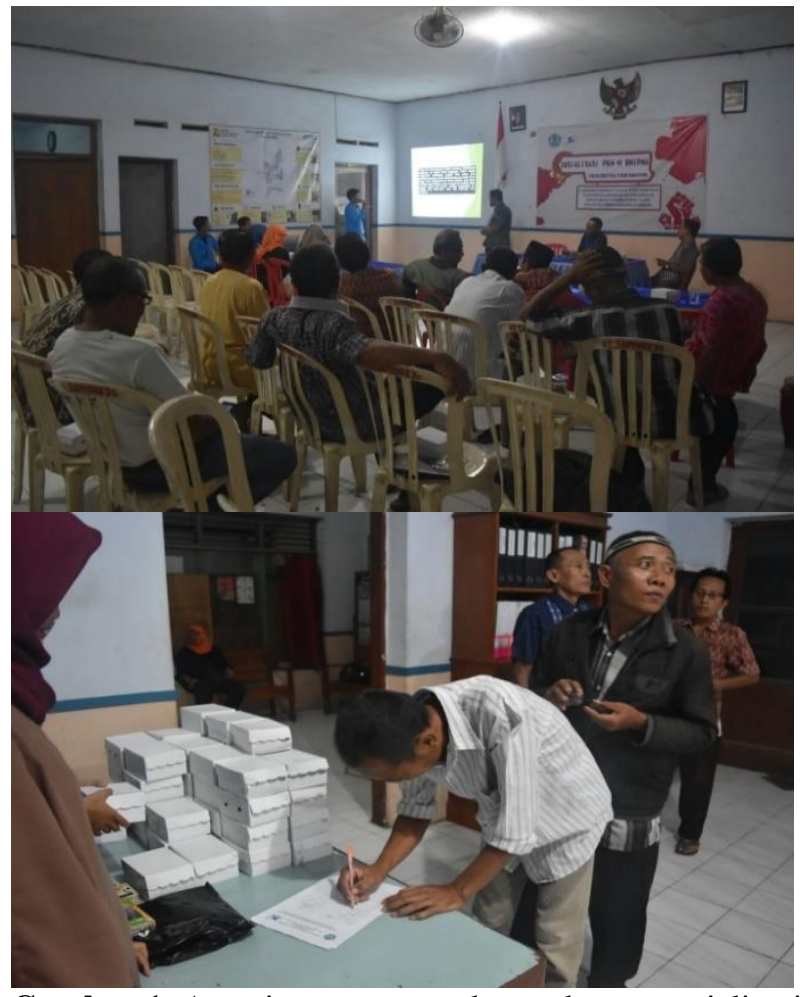

Gambar 1. Antusiasme masyarakat pada saat sosialisasi pemberdayaan masyarakat desa Sambirejo yang mengalami masalah pencemaran sungai melalui pembuatan B-Filma (Bio Filter Limbah Air Rumah Tangga) yang dilaksanakan di Balai Desa Sambirejo Kecamatan Jiwan Kabupaen Madiun.

Berdasarkan hasil angket yang diberikan kepada masyarakat Desa Sambirejo yang dibagikan setelah pelaksanaan sosialisasi, masyarakat ratarata mulai mengerti mengenai dampak dari pencemaran limbah air rumah tangga (khususnya limbah deterjen yang merupakan hasil aktifitas sehari-hari dan berdasarkan hasil kuisioner masyarakat desa sambirejo mulai mengenal adanya pembuatan alat B-FILMA sebagai solusi pengolahan limbah air rumah tangga dan sebagai cara untuk mengolah limbah air rumah tangga (khususnya limbah deterjen) sebelum dibuang ke selokan yang nantinya akan menguara ke sungai.

Untuk selisih hasil kegiatan sosialisasi pemberdayaan yang dicapai dan analisis kuisioner yang dibagikan sebelum sosialisasi dalah $50 \%$ masyarakat mengetahui dampak dari limbah air rumah tangga khususnya deterjen dan $20 \%$ masyarakat mengetahui alat B-FILMA, dan analisis hasil kuisioner yang dibagikan setelah sosialisasi adalah $75 \%$ masyarakat menjadi faham mengenai dampak dari limbah air rumah tangga 
khusunya deterjen dan $50 \%$ masyarakat mengetahui alat B-FILMA.

Tabel 1. Data hasil kuisioner masyarakat terhadap pengetahuan masyarakat desa Sambirejo akan pencemaran limbah air rumah tangga serta adanya penerapan alat B-FILMA sebagai salah satu solusi untuk mengolah dan menanggulangi pencemaran limbah air rumah tangga. (Data hasil kuisioner yang dibagikan sebelum adanya sosialisasi )

\begin{tabular}{|r|l|c|c|c|}
\hline \multirow{2}{*}{ No. } & \multicolumn{1}{|c|}{ Keterangan } & \multicolumn{2}{c|}{ Jumlah Jawaban } & \multicolumn{2}{c|}{$\begin{array}{c}\text { Total } \\
\text { Persentase }\end{array}$} \\
\cline { 3 - 4 } 1. & $\begin{array}{l}\text { Masyarakat mengetahui bahaya dari limbah air rumah tangga } \\
\text { (khususnya limbah deterjen) }\end{array}$ & $50 \%$ & $50 \%$ & $100 \%$ \\
\hline 2. & $\begin{array}{l}\text { Masyarakat mengetahui cara mengolah limbah air rumah tangga } \\
\text { (khususnya limbah deterjen) sebelum dibuang ke selokan yang } \\
\text { akan menguara ke sungai }\end{array}$ & $40 \%$ & $60 \%$ & $100 \%$ \\
\hline 3. & Masyarakat sadar akan pentingnya menjaga lingkungan & $50 \%$ & $50 \%$ & $100 \%$ \\
\hline 4. & $\begin{array}{l}\text { Masyarakat mnegatahui bahwa alat B-FILMA dapat mengolah } \\
\text { limbah air rumah tangga (khususnya limbah deterjen) }\end{array}$ & $20 \%$ & $80 \%$ & $100 \%$ \\
\hline
\end{tabular}

Tabel 2. Data hasil kuisioner masyarakat terhadap pengetahuan masyarakat desa Sambirejo akan pencemaran limbah air rumah tangga serta adanya penerapan alat B-FILMA sebagai salah satu solusi untuk mengolah dan menanggulangi pencemaran limbah air rumah tangga. (Data hasil kuisioner yang dibagikan setelah adanya sosialisasi)

\begin{tabular}{|r|l|c|c|c|}
\hline \multirow{2}{*}{ No. } & \multicolumn{1}{|c|}{ Keterangan } & \multicolumn{2}{c|}{ Jumlah Jawaban } & \multicolumn{1}{c|}{$\begin{array}{c}\text { Total } \\
\text { Persentase }\end{array}$} \\
\cline { 3 - 4 } & Tahu & Tidak tahu & \\
\hline 1. & $\begin{array}{l}\text { Masyarakat mengetahui bahaya dari limbah air rumah tangga } \\
\text { khususnya limbah deterjen) }\end{array}$ & $75 \%$ & $20 \%$ & $100 \%$ \\
\hline 2. & $\begin{array}{l}\text { Masyarakat mengetahui cara mengolah limbah air rumah } \\
\text { tangga (khususnya limbah deterjen) sebelum dibuang ke } \\
\text { selokan yang akan menguara ke sungai }\end{array}$ & $70 \%$ & $30 \%$ & $100 \%$ \\
\hline 3. & Masyarakat sadar akan pentingnya menjaga lingkungan & $80 \%$ & $20 \%$ & $100 \%$ \\
\hline 4. & $\begin{array}{l}\text { Masyarakat mnegatahui bahwa alat B-FILMA dapat mengolah } \\
\text { limbah air rumah tangga (khususnya limbah deterjen) }\end{array}$ & $75 \%$ & $25 \%$ & $100 \%$ \\
\hline
\end{tabular}

Berdasarkan hasil dokumentasi, menunjukkan antusiasme dan minat masyarakat dalam sosialisasi pemberdayaan masyarakat desa Sambirejo yang mengalami masalah pencemaran sungai melalui pembuatan B-Filma (Bio Filter Limbah Air Rumah Tangga).

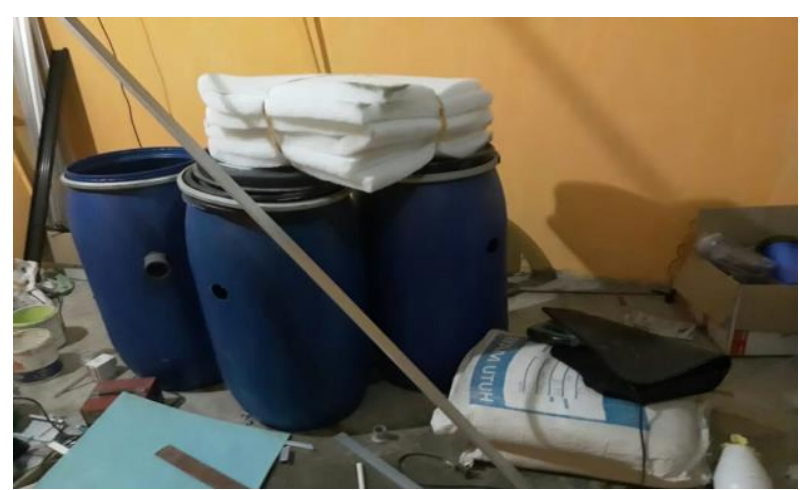

Gambar 2. Alat pembuatan B-Filma (Bio Filter Limbah Air Rumah Tangga).

\section{Kesimpulan}

Program

sosialisasi pemberdayaan masyarakat dalam pembuatan -Filma (Bio Filter Limbah Air Rumah Tangga adalah: (1) Memberikan pemahaman kepada masyarakat bahwa pentingnya menjaga kebersihan lingkungan..; (2) Memberikan pemahaman kepada masyarakat bahwa pentingnya menjaga kebersihan lingkungan; (3) Meningkatkan sumber daya manusia serta ikut peduli terhadap lingkungan sekitar; (4) Masyarakat diharapkan dapat membuat alat B-FILMA untuk mengoalah limbah air rumah tangga (khususnya limbah deterjen) dan memanfaatkannya kembali.

\section{Ucapan Terima Kasih}

Penulis mengucapkan terimakasih yang sebesar-besarnya kepada Kemenristekdikti selaku pemberi dana Program Kreativitas Mahasiswa 
Pengabdian Masyarakat dan Universitas PGRI Madiun yang selalu memberi dukungan penuh sehingga program ini dapat diseleseikan dengan baik. Dan juga kepada Dosen Pembimbing Ibu Pujiati S.Si., M.Si yang senantiasa memberikan arahan demi keberhasilan kegiatan ini.

\section{Daftar Pustaka}

Ahsan S. 2005. Effect of Temperature on Wastewater Treatment with Natural and Waste Materials [Original Paper]. Clean Technology Enviroment Policy. 7:198-202.

Anonimous 2009. Pengolahan Limbah Deterjen dengan Biofilter. http://www. greenradio.fm. [01 Juni 2018].
Heryani. A, Puji, H. 2008. Pengolahan Limbah Deterjen Sintetik dengan Trickling Filter[Makalah Penelitian] http://eprints.undip.ac.id [01 Juni 2018].

Rubiyatadji R. 1993. Penurunan Kadar Deterjen (Alkyl Benzene Sulphonate) Dalam Air Dengan Proses Adsorpsi Karbon Aktif. Tugas Akhir. Program Studi Teknik Lingkungan, ITS, Surabaya.

Widiyani, P. 2010. Dampak Dan Penanganan Limbah Deterjen. Program Studi Kesehatan Masyarakat Veteriner Fakultas Kedokteran Hewan Institut Pertanian Bogor. 